\title{
FACTORS RESPONSIBLE FOR WOMEN LOW PARTICIPATION IN POLITICAL LEADERSHIP IN AWKA-SOUTH LGA OF ANAMBRA STATE: PRACTICE CONSIDERATION FOR NIGERIAN BASED SOCIAL WORKERS
}

\author{
Chinyere E. Onalu \\ Department of Social Work \\ University of Nigeria, Nsukka
}

\author{
Nneka F. Nwafor \\ Department of Social Work \\ University of Nigeria, Nsukka
}

\begin{abstract}
Background: Historically, leadership has carried the notion of masculinity and the belief that men make better leadership than women. In the pre-colonial and colonial Nigeria, women never enjoyed parity with men on issue of governance; the same is witnessed in the post-colonial era. This study therefore explore the factors responsible for women low participation in political leadership in Awka-South Local Government Area of Anambra State and practice consideration for Nigeria based Social workers. Methodology: Questionnaire was used to collect data from respondents $(\mathrm{N}=574)$. Statistical Package for Social Sciences (SPSS) was adopted to analyse the quantitative data. The data were subjected to chi square and binary logistic regression analysis. Result: The findings show that level of education $(62.6 \%)$, wealth status $(69.5 \%)$, age $(81.6 \%)$, and place of residence $\mathbf{5 8 . 0 \% )}$ were found to affect women participation in political leadership and decision making. Conclusion: The study identified the need to establish leadership centers in all the LGAs. This centre will be responsible for teaching leadership skills for both males and females. Social workers are expected to enlighten women on the important of them participating in political activities.
\end{abstract}

Keywords - Women Low participation, Political Leadership, Awka-South and Social Worker

\section{INTRODUCTION}

The exclusion of women in political leadership and decision making was one inherited by human history. Women on their own as well, for a variety of reasons tends to be reluctant or lack the courage to participate in political leadership (Kassa, 2015). According to Kiamba (2008), in all African societies, it is common in rural villages in Africa to find the man literally walking ahead, while the woman follows. This scenario symbolizes the African belief that men make better leaders than women that is why history of Leadership in Africa connotes masculinity (Kiamba, 2008). In Kenya, Andela, et al. (2008) stated that leadership is strictly a man's role and viewed as inconsistent with the values of a "good woman", as a result, men does not support the leadership pursuit of their wives. Also in Ethiopia women are still regarded as inferior species and that limits their support in leadership positions (Hora, 2014). In Nigeria the story did not change, women have never enjoyed parity with men on issues of governance.

It is worth knowing that Africa operates a strong patriarchal system of autocracy which also reflects in her political structure. The colonial state was not able to alter it, despite the United Nation's recognition of the principle of equality of men and women in $1945 \mathrm{UN}$ charter and the subsequent universal declaration of human rights (UDHR) in 1948 (Kasomo, 2012). However, any country where women have historically been relegated to domestic affairs and excluded from public life, such barriers to participation in political leadership and decision will be much higher. The cultural construction of leadership in Africa itself instigates difference and this is only now being challenged as women gain access to leadership positions. Women are active politically more than they were decades ago, however, the bone of contention is the low percentage of women participating in political leadership position and decision making (Amu, 2016).

Female constitute more than half of the world's population, despite this fact, the political area have continued to be dominated largely by men at all levels of government (Kassa, 2015). The population census figure in 2006 shows that women constitute $49 \%$ of the total population in Nigeria; yet there has been a gross gender gap between men and women, especially in political leadership (Okafor \& Akokuwebe, 2015). Available statistics revealed a high level of disparity in levels of gender diversity at top management positions in Nigeria (Mordi, Adedoyin \& Ajonbadi, 2011). In 


\section{International Journal of Engineering Applied Sciences and Technology, 2020 Vol. 4, Issue 9, ISSN No. 2455-2143, Pages 41-49 \\ Published Online January 2020 in IJEAST (http://www.ijeast.com)}

the case of labour force in Nigeria, there is a dispassionate disparity in gender, of all the civil servants employed by the federal civil service, men represents up to $76 \%$ while women represents $24 \%$ with less than $14 \%$ in the total management level positions (Goldstar, 2005 \& 2006). In Lagos state, private sector involvement of women as directors and top management were $13.87 \%$ in 2005 and $13.11 \%$ in 2006 (Goldstar, 2006/2007).

The recognition of women in the political discourse is a recent phenomenon because it was only recognized as a political right after the adoption of the Universal Declaration of human right (UDHR) in 1948 (Kassa, 2015). Over the decades, the issues concerning women and their participation in leadership and decision making positions have taken on new dimensions. According to Kassa (2015), women's participation in political leadership has been recognized across the world as important. Efforts have been made to ensure women's participate in decision making and political leadership, however, women remain underrepresented in most prestigious position (Abegaz \& Asfaw, 2018). According to Growe and Montgomery (2012) the number of women in political leadership has increased, though they are mostly used as a substitute and afterthought, this is because women receive little or no encouragement to seek for leadership positions compared to men. Amadi and Amadi (2013) reported that the rise of the civil activism in the 1980s and the emergency of gender transformation that followed it saw to the rise of gender based Non-Governmental Organizations, which became a platform through which women's voice, were heard in relevance to politics. During this period Africa witnessed different women's groups forming alliances which includes:

(a) Gender development institute Nigeria

(b) Rural Nigeria women network

(c) National council for women society (NCWS)

(d) Ghana national council of women and development

(e) Tanzania media women association (TAMWA)

(f) The collaborative centre for gender \& development Kenya etc

Also in the 1990s, the role played by women during apartheid and the subsequent release of Nelson Mandela gave rise to more gender equality campaigns. A key historic landmark in African that aroused women participation in decision making and political leadership was the Presidential election in Liberia in 2005; where a woman emerged as national president for the first time in the history of African political leadership arena (Amadi \& Amadi, 2013). Also, many global conferences were held which aroused women's curiosity and desire for participating in politics and involvement in decision making. These conferences includes the Beijing conference of 1995 , the Cairo conference on population and development in 1994, the fourth world conference on women in 1995, and the world summit for social development in 1995; yet despite the progress made globally in improving status of women, gender disparities still exists. Kasomo (2012) observed that in spite of the international declarations and affirmations on the rights and equality between men and women, women still constitute a disproportionately small percentage of those participating in political leadership and decision making positions. The study maintains that the importance of inclusion of women to occupy political leadership and decision making positions cannot be over-emphasized as no society that seeks to develop can do so without involving the women.

On the other hand, Social work as a profession has enormous responsibility in this regard. According to Parrish (2010), Social work entails working with complex multi generational situations which makes having a clear understanding of developmental implications a crucial element of providing accurate assessment of problems. Through Social intervention, women can benefit from programmes that will help them participate in leadership and decision making positions and Social workers are better placed to provide such interventions. They can achieve this through organizing enlightenment campaigns against gender discrimination, obnoxious social norms, stereotyping, political exclusion and economic lopsidedness which have kept some women in disadvantaged position of not participating in public life. According to Amu (2016), lack of political orientation is one of the factors that hinder women's participation in political leadership positions in Nigeria. Therefore Social workers are in a position to reorient women on political leadership and decision making process. They can also advocate for policies and programmes that will motivate women to seek leadership and decision making positions. This will help the women to address issues that are inimical to women development, and also help them to contribute meaningfully to societal development. This is because according to Okafor and Akokuwebe (2015), women are major stakeholders in the development project of any society.

Factors that affect women's participation in leadership and decision making positions are different across the world and changing with the dynamic nature of the environments in which they live (Badjo \& Dickson, 2001; Chen \& Li, 2005). As Powell, et al. (2002); and Bartol, et al. (2003) puts it, Africa tradition has been pinpointed as a persistent hindrance in the active pursuit of women to obtain leadership positions (Hoyt, 2005). Researchers agree that low participation of women in political leadership and decision making positions in Nigeria may be as a result of some socio-economic, sociocultural, socio-demographic, political, ideological and psychological factors which include: age, gender, cultural patterns, ideology, marital status, pre-determined social roles assigned to women, male dominance and control, level of education and illiteracy, poverty, unemployment, lack of confidence, lack of access to information, lack of support especially from spouse, conflicting demands on time of women among others (Effah, 2012; Muoghalu, \& Abrifor, 2012; Nwosu, Oforka, Okolo \& Onigbo, 2012; Afolabi, 2010; Agbalajobi, 2009). According to Afolabi (2010), a number of these structures have aided the collective programming of the societal mind, making the underrepresentation of women in 


\section{International Journal of Engineering Applied Sciences and Technology, 2020 Vol. 4, Issue 9, ISSN No. 2455-2143, Pages 41-49 \\ Published Online January 2020 in IJEAST (http://www.ijeast.com)}

management, political leadership and decision making positions acceptable.

From the foregoing, it is evidently clear that a lot of challenges militate against women participation in political leadership and decision making positions. The study becomes imperative in the context of Awka South local government area as part of larger Nigerian society to explore the factors responsible for women low participation in political leadership in Awka-South Local Government Area of Anambra State and practice consideration for Nigeria based Social workers. It is based on this premise that this study will answer the following research questions: (a) To what extent do women participate in political leadership and decision making position? (b) What are the factors that affect women's participation in political leadership and decision making position?

\section{LITERATURE REVIEW}

\section{The concept of leadership}

There was a time that it was believed that leaders were born with certain leadership traits. However, current thinking on leadership assumes that leadership can be taught and learned, hence the many leadership-training programs (Cheryl, 2005). Growe and Montgomery (2012) defined leaders as people who provide vision and meaning for an institution and embody the ideals toward which the organization strives. In the same vein, Cheryl (2005) depicts leaders as those in the forefront who pull followers after them, sharing the way rather showing the way. As such, leadership should involve influencing others through the personality or actions of the individual leader (Growe and Montgomery, 2012). From these perspectives, leaders are alike and genderless. However there is still skepticism when women lead and in many situations, gender, more than age, experience or competence determines the role (position) one is assigned.

\section{Women's participation in political leadership and decision making process}

Several studies have been carried out throughout the world on women participation in political leadership and decision making positions. Women within a particular society are affected by the following factors: (a) the business environment, including taxes, procedures, corruption, labour, competition, low income and finances (World bank, 2007, 2008a; Bertrand, Djankor, Hanna \& Mullcinathan, 2007; Sharma, 2007; Titrek, Bayrakci \& Gunes, 2014); (b) fundamental social and developmental considerations like education, health and the physical environment (Lieb \& Thistle, 2005; Vliert, 2003); (c) economic factors and the level of development of a country, including the types of goods that are exported and services that provide a competitive advantage (Hill, 2008b; UNDP, 2007; Papamarcos \& Watson, 2006); (d) technological and distribution of infrastructure (Chan \& Qingyang, 2006; UN, 2005b); (e) the political rights and civil liberties within a country (House, 2008; Puddington, 2008); and (f) the beliefs, norms, and expectations of the individuals within a particular culture (Leunge \& Bond, 2004). Others are place or state of residence as well as age (Losindilo, Mussa \& Akarro, 2010).

Studies have demonstrated that there are few women leaders or role models for women in the sub-Saharan region (Maathai, 2006; Sikazwe, 2006). Moreover, sub-Saharan cultures have historically excluded women from leadership positions and confined the work of women to the home environment. Excluding women's input by holding back their involvement in education, leadership, and financial and social progress has a negative impact on development and society at large (Chisholm, 2001; Kevane, 2004; Mutindi, 2001). The result of such exclusion is that women become dependants rather than active co-producers, which deals a loss to the economy. Accordingly, encouraging women to take on leadership positions in corporate and not-for-profit organizations is beneficial not only to the women themselves but also to the entire society, since shared leadership roles may bring new perspectives.

Sadie (2005) advanced the argument that at the bottom of the constraints that women face is the patriarchal system where decision making powers are in the hands of males. In the African context, traditional beliefs and cultural attitudes regarding the role and status of women in society are still prevalent and many women are part of this system finding it difficult to dislocate from this culture and tradition lest they be ostracized. Despite women's education and entry into the job market, the woman's role is typically one of homemaker. The man, on the other hand, is bread winner, head of household and has a right to public life (Sadie, 2005).

The socialization of the girl child in many societies is also to be blamed for perceived inabilities on the part of women. As observed by Emmet (2001), all mainstream religions have stereotypical roles for men and women where women are perceived as less equal than men, often being kept separate in the way roles are assigned. There are also few social networks (formal and informal) for women such as membership in clubs, resulting in a lack of recognition that leads to advancement. Administrative/leadership positions require hard work, long hours and are stressful. For women, this burden is added on to their child-care, home, and family responsibilities (Sadie, 2005). Hojgaard (2002) looked at marital status, presence of children and distribution of work at home. The male leaders were more likely to be married, while a higher proportion of women leaders were divorced or independently living together. Furthermore, the partners of female leaders were also more likely to be working full time, while among the partners of male leaders (especially business leaders) there was a high proportion of part time work and full time housewives. Two thirds of male leaders did little or no housework, indicating that most male leaders (unlike female leaders) are relieved of the burdens associated with family life and can devote all their energy to their jobs.

This became imperative as the issue of women's empowerment and gender equality is at the top of agenda for 


\section{International Journal of Engineering Applied Sciences and Technology, 2020 Vol. 4, Issue 9, ISSN No. 2455-2143, Pages 41-49 \\ Published Online January 2020 in IJEAST (http://www.ijeast.com)}

social workers across the world, as gender inequality is widespread in all cultures and if serious steps to tackle it, sustainable development cannot be achieved (Stevens, 2010). To this end, it is the responsibility of social workers to promote mainstreaming of women into political and decision making positions as gender equality is both a human rights issue and a precondition for, and indicator of, sustainable development (Alvarez, 2013). Furthermore, UN Women (2014) rightly outlined that to create a just and sustainable world and to enhance women's roles in sustaining their families and communities, achieving gender equality is paramount. On the other hand, if gender equality is not maintained, it will retard the country's development. There is need to position women so that they can take on the enormous responsibility of participating in political leadership and decision making position.

\section{THEORETICAL FRAMEWORK}

This study adopted the feminist and empowerment theories as its framework of analysis. The major tenets of the theories which focused on the liberation of the oppressed as well as studying the problems of women in the society who are often denied equal opportunity to participate in political leadership and decision making positions are part of the reason that these theories are suitable for this study. In trying to help women to end men's domination in leadership positions, these theories advocated for equal opportunity between men and women in all endeavours of life as well as educating women about their rights. This is important because according to Okafor and Akokuwebe (2015), women are major stakeholders in the development project of any society. Therefore, in order to ensure a fair and just society where women can develop their full potentials, there must be a deliberate effort to help women to participate in political leadership and decision making positions.

\section{STUDY AREA}

The study was conducted in Awka South area of Nigeria. The area is situated in Anambra state which is an Ogbo society. It plays host to the famous Nnamdi Azikiwe University, Awka. The choice of this area for the study was because it's part of the Nigerian patriarchy society where women face daunting challenges trying to ascend to political leadership and decision making positions (Muoghalu \& Abrifor, 2012). For example since the creation of Awka-South LGA, it was only once that a woman was elected as the chairman of the local government. Secondly the researcher originates from the LGA and this can enhance the feasibility of the study.

The 2006 census puts the population of the area at 189,654 persons consisting of 96,902 males and 92,752 females (National Bureau of Statistics, 2010). However, with an annual growth rate of $2.3 \%$ as supplied by National Population commission [NPC] (2006), the 2016 population of Awka South LGA was put at 250, 900 persons with. The target population of this study will be adult females who are up to 18 years and above, resident in the local government area. The essence of adopting these set of people is because it is assumed that they must have in one way or the other involved or witnessed low participation of women in political leadership and decision making positions. Hence, they will be able to respond appropriately to the issues that will be raised in the questionnaire.

\section{DATA TYPES AND SOURCE}

A multi stage sampling procedure which entails successive selection of community clusters, groups, streets, villages, housing units and respondents was used. The area was grouped into two major clusters $\mathrm{A}$ and $\mathrm{B}$, while cluster $\mathrm{A}$ represents urban, cluster $B$ represent rural areas. The urban community is made up of heterogeneous population in the sense that some of the inhabitants are from various areas. Also, the dwelling units or compounds are arranged using street numbers. The rural communities are made up of homogenous population because the inhabitants are mostly indigenes of the area and they share common language, culture and value system. The choice of the use of an urban and rural area is to help the researcher get varied demographic data that will be used to analyze the respondents' views on the subject of study.

The researcher purposively selected Awka town as it is the only urban area while simple random sampling (SRS) (balloting) was used to select two communities from the rural communities. This is to balance the study population as the population of urban dwellers out numbers that of rural dwellers. A total of 50 respondents were selected from the street using purposive sampling and that give a total of 300 respondents for the urban area.

Using purposive sampling one eligible member was selected from each household in the rural areas taking into account the age variable. Households that do not have a person with the required characteristics were substituted with other households until the desired number of the respondents was achieved. For the household that had two or more person within the required age range, one of them was selected using SRS (balloting). Giving the sample size of 300 respondents for the rural communities also, the researcher selected 50 respondents from each village, added to the 300 respondents from the urban community give you a total of 600 respondents for questionnaire distribution

\section{VARIABLE DESCRIPTION}

The study had five independent variables and one dependent variable. The independent variables include the marital status, level of education, level of income, age and place of residence while the dependent variables is low participation in political leadership and decision making positions. The variables were used because of its impact on the study. Women participation in leadership may be influence by the age and their place of 


\section{International Journal of Engineering Applied Sciences and Technology, 2020 \\ Vol. 4, Issue 9, ISSN No. 2455-2143, Pages 41-49 \\ Published Online January 2020 in IJEAST (http://www.ijeast.com)}

residence (rural and urban), it can equally be affected by the financial strength and level of exposure. These explain the effects of these variables and low participation of women in leadership.

\section{DATA ANALYSIS}

The analysis was based on the respondent's views from the questionnaire. The questionnaire was coded; computer processed and analyzed using the Statistical Package for Social Sciences (SPSS) version 20.

\section{RESULTS}

\section{Socio-demographic characteristics of respondents}

Socio demographic characteristics of respondents show that more than $56 \%$ of the respondents were married, while more than $43 \%$ were either single or divorced. Also more $36 \%$ of the respondents were between the ages of $18-33$ years; more than $52 \%$ were within the age of $34-$

Table 1: Socio-demographic characteristics of respondents

\begin{tabular}{lll}
\hline $\begin{array}{l}\text { Variables } \\
\text { Marital status }\end{array}$ & $\mathrm{N}=574$ & $\%$ \\
$\begin{array}{l}\text { Married } \\
\text { Unmarried }\end{array}$ & 324 & 56.4 \\
Level of education & 250 & 43.6 \\
$\begin{array}{l}\text { Higher education } \\
\text { Lower education }\end{array}$ & 310 & 54 \\
Age & 264 & 46 \\
Young & 211 & \\
Middle age & 302 & 36.8 \\
Old & 61 & 52.6 \\
Place of residence & & 10.6 \\
Urban & 287 & 50 \\
Rural & 287 & 50 \\
\hline
\end{tabular}

49, while those from 50 years and above were $10.6 \% .54 \%$ of the respondents were graduates and some obtained higher university degrees, and $46 \%$ of the respondents were those without formal education and non-graduates.

Table 2: Factors that affects women's participation in political leadership

\begin{tabular}{|c|c|c|}
\hline \multirow{2}{*}{\multicolumn{3}{|c|}{$\begin{array}{l}\text { Factors } \quad \text { Frequency } \\
\text { Can lack of education affect women's participation in political } \\
\text { leadership and decision making positions. }\end{array}$}} \\
\hline & & \\
\hline It will affect them a lot & 365 & 63.6 \\
\hline It will affect them & 176 & 30.7 \\
\hline It will not affect them & 26 & 4.5 \\
\hline It will not affect at all & 7 & 1.2 \\
\hline $\begin{array}{l}\text { Can financial resour } \\
\text { political leadership anc }\end{array}$ & $\begin{array}{l}\text { es affect } \\
\text { decision } \mathrm{m}\end{array}$ & $\begin{array}{l}\text { participation in } \\
\text { ition. }\end{array}$ \\
\hline Very much & 357 & 62.2 \\
\hline Much & 169 & 29.4 \\
\hline Very little & 30 & 5.2 \\
\hline
\end{tabular}

$\begin{array}{lll}\text { Little } & 8 & 1.4 \\ \text { Not at all } & 10 & 1.7\end{array}$

Which age bracket of women participate more in political leadership and decision making positions

$\begin{array}{lrl}15-24 & 15 & 2.6 \\ 25-34 & 40 & 7.0 \\ 35-44 & 177 & 30.8 \\ 45-54 & 276 & 48.1 \\ 55 \text { and above } & 66 & 11.5\end{array}$

Can obnoxious cultural practices affect women's participation in political leadership and decision making positions

It will affect them a lot 323

It will affect them $\quad 167 \quad 29.1$

It will affect them $\quad 77 \quad 13.4$

It will not affect at all $\quad 7 \quad 1.2$

In determining how education as factors will affects women's participation in political leadership and decision making positions, $63.6 \%$ of the respondents are of the view that lack of education will affect women a lot in political leadership and decision making positions, $30.7 \%$ affirmed it will affect them, $4.5 \%$ said it will not affect them while $1.2 \%$ believe it will not affect them at all. This indicated that overwhelming majority affirmed that lack of education will affect women in political leadership and decision making positions. Also considering the factor of financial resources, $62.2 \%$ believe that financial resources will affect women very much in political leadership and decision making positions, $29.4 \%$ believe it will affect them much, $5.2 \%$ believe it will affect them very little, $1.4 \%$ believe it affect them little while $1.7 \%$ suggested it will not affect them at all. This indicated that overwhelming majority affirmed that financial resources will affect women in political leadership and decision making positions. Furthermore, on the factor of age bracket, the table showed that $2.6 \%$ of the respondents think that women between the ages of 15-24 participate more in politics, $7.0 \%$ believe that women between the ages of 25-34 participate more, $30.8 \%$ believe that women between the ages of 35-44 participates more, $48.1 \%$ believe that women between the ages of 45-54 participate more while $11.5 \%$ believe that women between 55 and above participates more. This indicated that majority of the respondents believe that women between the ages of 45-54 years participate more in politics. This is followed by those within the ages of 35-44, 50 and above, 25-34 and 15-24 years respectively. Finally on the factor of obnoxious cultural practices, $56.3 \%$ agreed that obnoxious cultural practices will affect women a lot in political leadership and decision making positions. $29.1 \%$ agreed that it will affect them, 13.4\% agreed it will not affect them while $1.2 \%$ agreed that it will not affect them at all. From the table, it shows that majority of the respondents believe that obnoxious cultural practice will affect women a lot in participating in political leadership and decision making position 


\section{International Journal of Engineering Applied Sciences and Technology, 2020 Vol. 4, Issue 9, ISSN No. 2455-2143, Pages 41-49 \\ Published Online January 2020 in IJEAST (http://www.ijeast.com)}

Table 3: Association between selected factors and women participation in political leadership and decision making

\begin{tabular}{|c|c|c|c|}
\hline Variable & Participate & Not participate & \\
\hline & $\%$ & $\%$ & chi square \\
\hline \multicolumn{4}{|c|}{ Marital status } \\
\hline Single & 47.7 & 41.8 & \multirow[t]{2}{*}{.186} \\
\hline Married & 52.3 & 58.3 & \\
\hline \multicolumn{4}{|c|}{ Educational level } \\
\hline Lower & 37.4 & 19.5 & \multirow[t]{2}{*}{.000} \\
\hline Higher & 62.6 & 80.5 & \\
\hline \multicolumn{4}{|c|}{ Level of income } \\
\hline Lower inc & ne 69.5 & 62.5 & \multirow[t]{2}{*}{.063} \\
\hline Higher in & ne 30.5 & 37.5 & \\
\hline \multicolumn{4}{|c|}{ Age } \\
\hline Younger & 81.6 & 60.2 & \multirow[t]{2}{*}{.000} \\
\hline Older & 18.4 & 39.8 & \\
\hline \multicolumn{4}{|c|}{ Place of residence } \\
\hline Urban & 42.0 & 53.5 & \multirow[t]{2}{*}{.011} \\
\hline Rural & 58.0 & 46.5 & \\
\hline
\end{tabular}

Association is significant at $\mathrm{p}<0.05$

This section deals with explanation of association between selected factor affecting women participation in political leadership and decision making. The analysis was done by cross tabulating selected independent variable with women involvement in decision making. All the variables were tested at 0.05 level of significant, and the result showed that level of education, level of income, age, and place of residence were significantly associated with women participation in political leadership and decision making. About $37.4 \%$ of respondents with lower education participated in political leadership and decision making and $19.5 \%$ did not participate. Also about $69.6 \%$ of respondents with lower income participated in political leadership as compare to $30.5 \%$ with higher income. However, in the age, older respondents with about $39.8 \%$ respondents did not participate in political leadership while only 18.4 participated.

Table 5: Table 5: Binary logistic regression model predicting factors affecting women participation in political leadership and decision making in Awka-South LGA

\begin{tabular}{|l|c|l|l|}
\hline Predictors & $\begin{array}{l}\text { Beta } \\
\text { Coefficient }\end{array}$ & $\begin{array}{l}\text { Level of } \\
\text { Significance }\end{array}$ & $\begin{array}{l}\text { Odds } \\
\text { Ration }\end{array}$ \\
\hline Marital status & .165 & .474 & 1.179 \\
\hline $\begin{array}{l}\text { Level of } \\
\text { Education }\end{array}$ & 2.499 & $.000^{*}$ & 12.175 \\
\hline Wealth status & -.387 & .101 & .681 \\
\hline Age of & -4.240 & $.000^{*}$ & 24699 \\
\hline $\begin{array}{l}\text { Place } \\
\text { Residence }\end{array}$ & .651 & $.027^{*}$ & 2.471 \\
\hline
\end{tabular}

Significant at $\mathrm{P}<0.05$

Source: Author's Computation, 2019
Utilizing the five socio-demographic status of the respondents as independent variables, their relationship with the women participation in political leadership and decision making in the study area was assessed with the Binary logistic regression analysis. Being single, with low level of education, lower income, young and residing in rural area is constituted the reference categories in the analysis. Using a Beta coefficient of .165, marital status recorded a positive relationship as a predictor of women participation in political leadership and decision making. Therefore being married increases the chance of participating in political leadership and decision making by .165 units. The odd ration for the independent variable (marital status) as shown in table 4 is given as 1.179 and also was not statistically significant. Level of education, income level, age and place of residence significantly predict participation in political leadership in the study area.

\section{DISCUSSION}

The study investigates the factors affecting women participation in political leadership and decision making in Awka-South local government area of Anambra state. Among the socio-demographic variables, age of the respondents was significantly associated with their participation in political leadership and decision making. It was found that the younger women are $81.6 \%$ more likely to participate in political leadership than the older women with $60.2 \%$. The reasons for this may most likely be associated with the younger women in Awka-North ability to embrace change due to their awareness of the importance of participation in political leadership compared with the older women. Other reasons maybe as a result of societal orientation, personal interests, access to social media and technologies of information, and other exposures. The younger women in Awka-South are more exposed to the internet due to youthful exuberance. Their high level of participation in leadership position and decision making maybe for what they will gain (i.e. material benefits). Surprisingly, this finding is contrary with a study carried out by Le (2011), who reported that women encountered more challenges in filling their roles when they were younger as they were overwhelmed with huge workloads and domestic duties as compared to when they are older. In the same vein, the findings of Losindilo et al, 2010, also found out that older women between 40 to 70 years participate in political and decision making positions than women between 15 to 39 years.

Another socio-demographic variable which had association with the factors that affects women participation in political leadership and decision making in the study area is the place of residence. The result showed that out of all the respondents that said that they participate in any political activity, $42.0 \%$ were urban dwellers while $58.0 \%$ were rural dwellers. It was revealed that women in rural areas are 58.0\% more likely to participate in political leadership and decision making than $42.0 \%$ of those in the urban areas. This is in line 


\section{International Journal of Engineering Applied Sciences and Technology, 2020 Vol. 4, Issue 9, ISSN No. 2455-2143, Pages 41-49 \\ Published Online January 2020 in IJEAST (http://www.ijeast.com)}

with Bishaw (2013) who stated that rural women with primary and secondary school educational experience have claimed significantly higher participation in political and economic affairs and highly benefited from their participation. The finding is also similar to the findings of Losindilo, Mussa and Akarro (2010) which revealed that participation of women in political and decision making position is more pronounced in rural than in urban areas.

Another socio-demographic factor associated with women participation in political leadership is their financial status. Women with lower level of income are $69.5 \%$ more likely to participate in political leadership than $30.5 \%$ of those with higher income. Contrary to this, Fatile, Akhakpe and IgbokweIbeto (2012) revealed that lack of adequate finance is a crucial hindrance to effective female participation in Nigerian politics. This finding also contradicted the findings of Agbalajobi (2009) which found that low income earned by women also affects their participation in political leadership and decision making positions. According to him, political campaigns are expensive and require solid financial backing for success. Consequently, only few women that are affluent possess the economic power to bankroll political campaigns. In the same vein, Fatile, Akhakpe and Igbokwe-Ibeto (2012) agreed with these findings when they examined women political participation in Nigeria and the challenges facing them and found that lack of adequate finance is a crucial hindrance to effective female participation in Nigerian politics. In the case of Awka- south the reverse was the case probably because of the difference in society and orientation. Given that some women go into politics either to enrich their pocket. However when the quest for wealth is a propelling factor for participating in political leadership, it means that lack of money is an accomplice and therefore cannot be a limiting factor for women in Awka-south local government in terms of participation in political leadership and decision making.

Moreover, another socio-demographic factor associated with women participation in political leadership is level of education. Women with higher level of education are $62.6 \%$ more likely to participate in political leadership and decision making than $37.4 \%$ women with lower level of education. This finding is supported by the study of Titrek, Bayrakci and Gunes (2014) which studied barriers to women's leadership in Turkey and found that low levels of education among women were barriers to women's leadership in Turkey. Supporting these findings, Bishaw (2013) reported that rural women with primary and secondary school educational experience have claimed significantly higher participation in political and economic affairs and highly benefited from their participation compared to the illiterate rural women. Again, Goetz (2003) found that formal education is strongly associated with political participation for women. His findings revealed that education is an especially powerful predictor of political participation as it provides women with the acquisition of knowledge and communication skills useful for public debate, and direct training in political analysis which enhances other factors supporting political engagement, such as access to high-income jobs that provide the resources and contacts for political activity, and access to non-political associations such as charitable organizations or religious establishments that can be a recruitment ground for political activity. Based on the findings, the researchers recommend the following:

* There is an urgent need for a change in peoples' perception on women participation in political leadership and decision making positions. This is necessary as most people especially women still believe that ascension to political leadership and decision making positions is the exclusive of men. To achieve this, government through National Orientation Agency (NOA) should facilitate campaigns to educate people that women also have inherent ability to lead and that what is needed is to give them necessary support.

* There is a need to establish leadership centers in each local government area. This center will be responsible for teaching leadership skills for both males and females. Through this forum the leadership of potential of each individual will be explored and harnessed. It can also help exhibit leadership qualities of women.

* There is need for deliberate effort to include gender as courses in the curriculum of education (primary, secondary and tertiary). This will help to expose people the need to be fair in dealing with both males and also note that what is good for the goose is also good for the gander. Courses on gender will expose people to understand that women can do what men can do if given the opportunity.

* Each locality should be encouraged to engage women leadership position. This will create a sense of belonging and serve as a new way of socializing women into having interest in political leadership and decision making positions.

* Through enlightenment campaigns, government should establish the necessary infrastructure needed for the Social workers to introduce jingles and talk shows on the importance of involving women in political leadership and decision making positions through the media to cover a wider population of the country. This will help reduce suspicion and help secure a peaceful and stable nation.

\section{CONCLUSION}

The study revealed the factors that affect women participation in political leadership and decision making in Awka-South local government area of Anambra state. The study have provided empirical evidence that age, place of residence, level of income, level of education, and marital status are associated with women participation in political leadership and decision making in Awka-South local government area in Anambra state. In conclusion, the findings revealed that not many women had held political leadership and decision making 


\section{International Journal of Engineering Applied Sciences and Technology, 2020 Vol. 4, Issue 9, ISSN No. 2455-2143, Pages 41-49 \\ Published Online January 2020 in IJEAST (http://www.ijeast.com)}

positions in the area under study. However there seems to be a realization that women need to be encouraged to participate in political leadership and decision making positions. To this end, the government, organizations and Social workers should be quickly awakened to their separate responsibilities in enlightening the people about need to support women to occupy political leadership and decision making positions. This will provide opportunity for women to discuss the issues that affect them. Also it will help to balance the equation and give women sense of belonging such that they can contribute meaningfully to national growth and development.

\section{REFERENCE}

Abegaz S.T., and Asfaw W.D. (2018). Challenges with Implementing Political Leadership and Decisionmaking Participatory Rights for Women in Ethiopia. Journal of Comparative Law in Africa, (pp.45-72).

Afolabi A.A. (2010). Nigeria's Electoral Reform and the Prospect for Women's Participation in the 2011 Elections. https://www.gwiboell.de/en/2011/03/09/nigerias-electoral-reformand-prospect-womens-participation-2011-elections

Agbalajobi D.T. (2009). Gender, Power and Political Leadership in Nigeria: Problems and Prospects. African Journal for the Psychological Study of Social Issues, (pp.1-2).

Alvarez L. M. (2013). From Unheard Screams to Powerful Voices: A Case Study of Women's Political Empowerment in the Philippines. A Dissertation Submitted in Partial Fulfillment of the Requirements for the Degree of Master of International Development Policy, Graduate School of International Studies Seoul National University Seoul, Korea. http://nap.psa.gov.ph/ncs/12thncs/papers/INVITED/I PS19\%20Youth\%20and\%20Gender\%20Statistics/IP S19_2\%20From\%20Unheard\%20Screams $\% 20$ to $\% 20$ Powerful $\% 20$ Voices $\% 20$ A $\% 20$ Case $\% 20$ Study $\% 20$ of $\% 20$ Women $\%$ E2\%80\%99s\%20Political\%20Empowe rment\%20in\%20the\%20Philippines.pdf

Amadi L.; and Amadi C. (2015). Towards Institutionalizing Gender Equality in Africa: How Effective are the Global Gender Summits and Convention? A Critique. AJPSIR, (pp.12-26).

Amu O.S. (2016). Gender Equality: Factors Hindering Female Participation in Nigeria Politics. https://www.worldpulse.com/community/use rs/ohizzy/posts/66590

Andela, C.; Escandon, S.D.; Garlo, C.K., Kamungi, P.M. (2008). Women of Africa Leadership Development Program. https://www.sfcg.org/progra mmes/lwi/documents/WomenOfAfrica_Kenya.pdf

Bajdo L.M., and Dickson M.W. (2001). Perceptions of Organizational Culture and Women's
Advancement in Organizations: A Cross Cultural Exa mination.DOI: 10.1023/A:1014365716222

Bartol K.M., Martin D.C., and Kromkowski J.A. (2003). Leadership and the Glass Ceiling: Gender and ethnic Group Influences on Leader Behaviors at Middle and Executive Managerial Levels. Journal of Leadership \& Organizational Studies, 9, 8.

Bertrand M., Djankov S., Hanna R., and Mullcinathan S. (2007). Obtaining a Driving License in India: An Experimental Approach to Studying Corruption? Quarterly Journal of Economics, (pp.8-11).

Bishaw A. (2013). The Impact of Education on Rural Women's Participation in Political and Economic Activities. International Journal of Educational Administration and Policy Studies, (pp.23-31).

Chan S., and Qingyang G. (2006). Investment in China Migrates Inland. Far Eastern Economic Review, (pp.52-57).

Chen X.P., and Li S. (2005). Cross-National Differences in Cooperative Decision-making in Mixed-motive Business Contexts: The Mediating Effect of Vertical and Horizontal Individualism. Journal of International Business Studies, (pp.622-636).

Cheryl H. (2005). No Right to Choose: Mandated Victim Participation in Domestic Violence Prosecutions. Harvard Law Review, (pp.1849-1910).

Effah A.E. (2012). Problems Militating Against Women in Politics. http//www.online.nigeria.com/links/Asp.Htm.

Emmet M. (2001). Women at the Heart of a Renewed Vision for Humanity. http://www.managementjournal.info

Fatile O.J., Akhakpe I., Igbokwe-Ibeto C.J., and Oteh C.O. (2012). Feminism and Political Participation in Nigeria: An Empirical Analysis. International Journal of Asian Social Sciences, (pp.1077-1092).

Goetz A.M. (2003). Women's Education and Political Participation. UNESCO, (pp.2)

Goldstar D. (2006). Nigeria's Top 500 Companies (13th ed.). Lagos: Goldstar Directories.

Goldstar D. (2007). Nigeria's top 500 Companies (14th ed.). Lagos: Goldstar Directories.

Hill, C.W.L. (2008b). Global Business Today. New York: McGraw-Hill/Irwin.

Hojgaard L. (2002). Tracing Differentiation in Gendered Leadership: An Analysis of Differences in Gender Composition in top Management in Business, Politics and the Civil service. Gender, Work and Organization, (pp.15-38).

Hora E. A. (2014). Factors That Affect Women Participation in Leadership And Decision Making Position. Asian Journal of Humanity, Art and Literature, (pp.56-63).

House F. (2008). Political freedom index. http://www.freedomhouse.org

Hoyt C. L. (2005). The Role of Leadership Efficacy and Stereotype Activation in Women's Identification with 


\section{International Journal of Engineering Applied Sciences and Technology, 2020 \\ Vol. 4, Issue 9, ISSN No. 2455-2143, Pages 41-49 \\ Published Online January 2020 in IJEAST (http://www.ijeast.com)}

Leadership. Journal of Leadership \& Organizational Studies, https://doi.org/10.1177/10717919050110040 1

Kasomo D. (2012). Factors Affecting Women Participation in Electoral Politics in Africa. International Journal of Psychology and Behavioural Sciences, (pp.57-63).

Kassa, S. (2015). Challenges and Opportunities of Women Political Participation in Ethiopia. Journal of Global Economics, doi:10.4172/2375-4389.1000162.

Kevane, M. (2004). Women and Development in Africa. Boulder, CO: Lynne Reinner Publishers, Inc. https://www.rienner.com/uploads/47daa1bed114d.pdf

Kiamba J.M (2008). Women and Leadership Positions: Social and Cultural Barriers to Success. http://www.appweb.cortland.edu/ojs/index.php/waga du/article/view Article/352/668

Le N.T.T. (2011). How Does Culture Impact on Women's Leadership in Higher Education? A Case Study in Vietnam. New Zealand: University of Waikato, https://pdfs.semanticscholar.org/3a3c/e88224588e96c 930d3d3796f8d18c6dce38b.pdf

Lieb H., and Thistle S. (2005). Marriage, Work, Poverty, and Children: The Changing Impact of Marriage, Motherhood and Work on Women's Poverty. Journal of Women, Politics \& Policy, (pp.5).

Losindilo E.; Mussa A.S.; Akarro R.R.J. (2010). Some Factors That Hinder Women Participation in Social, Political and Economic Activities in Tanzania. Arts and Social Sciences Journal, (pp.1-10).

Maathai W. (2006). Unbowed: One Woman's Story. London: William Heinemann.

Mordi C.; Adedoyin H.; Ajonbadi H. (2011). Impediments to Women Career Advancement: The Nigerian experience. Economic Sciences Series, (pp.11-22)

Muoghalu C.O. and Abrifor C.A. (2012). Urban Poor Women and Governance in Nigeria. European Scientific Journal, (pp.176-180).

Mutindi M. K. (2001). Women's Agency and Educational Policy: The Experience of the Women of Kilome, Kenya. https://www.sunypress.edu/p-3266-womensagency-and-educational-p.aspx

National Population Commission, (2006). Population Census of the Federal Republic of Nigeria: Preliminary Report Abuja

Nwosu E. N., Oforka T. O., Okolo A. N., Onigbo L. N. (2012). Socio-cultural Factors as Correlates of Women's Participation in Politics in Nigeria. International Journal of Environment, Ecology, Family and Urban Studies, (pp.29-36).

Okafor E. E., and Akokuwebe M. E. (2015). Women and Leadership in Nigeria: Challenges and Prospects. Developing Country Studies, (pp.1-10).

Papamarcos, S. D., \& Watson, G. W. (2006). Culture's Consequences for Economic Development: An Empirical Examination of Culture, Freedom, and
National Market Performance. Journal of Global Business and Technology, (pp.48-58).

Parrish, M. (2010). Social Work Perspectives on Human Behavior. England: Open University Press.

Powell G. N.; Butterfield D. A.; Parent, J. D. (2002). Gender and Managerial Stereotypes: Have the Times Changed? Journal of Management, (pp.177-193).

Puddington A. (2008). Freedom in Retreat: Is the Tide Turning? Findings of Freedom in the World. Washington D.C.: Freedom House.

Sadie Y. (2005). Women in Political Decision Making in Southern Africa Region, (pp.17-31).

Sharma, S. (2007). Financial development and innovation in small firms. Washington, D.C: The World Bank.

Sikazwe E. J. (2006). Developing Women's Leadership Through Mentoring in Rural Communities of Zambia. Masters Abstracts International, (pp.2505).

Stevens C. (2010). Are Women the Key to Sustainable Development? Sustainable Development Knowledge Partnership (SDKP), USA.

Titrek M.B., and Gunes, D.Z. (2014). Valuing Science: A Turkish- American Comparison. International Journal of Science Education, (pp.401-421).

U.N, (2014). World survey on the role of women in development: Gender Equality and Sustainable Development. New York: UN

UN, (2005b). Investment in Development: A Practical Plan to Achieve the Millennium Development Goals. New York: United Nations Development Programme.

UNDP. (2007). Making Globalization Work for All: United Nations Development Programme Annual Report 2007. New York: UNDP.

Vliert E.V. (2003). Thermoclimate, Culture, and Poverty as Country-level Roots of Workers' Wages. Journal of International Business Studies, (pp.40).

World Bank (2007). Doing Business Report 2008: Comparing Regulations in 178 Economies. https://openknowledge.worldbank.org/handle/10986/ 6869

\section{Acknowledgement}

Our special gratitude goes to the Almighty God for His grace upon us and our love ones. We also express our unreserved gratitude to all the lecturers and staff in the Departments of Social work University of Nigeria Nsukka for their support and encouragement in the execution of this work. 